\author{
Kamila Ziółkowska-Weiss \\ Uniwersytet Pedagogiczny \\ im. Komisji Edukacji Narodowej \\ w Krakowie
}

\title{
Problematyka podstaw przedsiębiorczości w opinii uczniów szkoły ponadgimnazjalnej. Przydatność w życiu czy konieczność nauki?
}

\author{
Basics of Entrepreneurship in the eyes of upper secondary school students. \\ Useful in life or a necessity to learn?
}

\begin{abstract}
Streszczenie
Przedmiot podstawy przedsiębiorczości pomaga zrozumieć młodemu człowiekowi mechanizmy funkcjonowania gospodarki rynkowej, przygotowuje do planowania przyszłej kariery zawodowej, kształtuje kompetencje sprawnego komunikowania się, a także przygotowuje do planowania i realizacji przedsięwzięć w otaczającym go środowisku.

Niniejszy artykuł ma na celu ukazanie poglądów młodzieży dotyczących kilku spraw związanych $\mathrm{z}$ realizacją przedmiotu podstawy przedsiębiorczości w szkołach ponadgimnazjalnych. W artykule zostaną przedstawione wyniki badań, które zostały przeprowadzone w marcu $2013 \mathrm{r}$. na uczniach klas trzecich oraz pierwszych w Liceum Ogólnokształcącym w Andrychowie. Badania podjęto, aby dokonać analizy realizacji celów, zadań oraz treści kształcenia przedmiotu podstawy przedsiębiorczości. Głównym celem badań było zapoznanie się z opinią uczniów, które zagadnienia - według nich - są najbardziej przydatne w życiu dorosłym oraz które zagadnienia i treści najbardziej ich interesują. Analiza ankiet ukazała, jak bardzo różnią się zainteresowania i oczekiwania uczniów klas pierwszych i trzecich.

Uczniowie odpowiadali m.in. na pytania, czy treści przekazywane na lekcjach podstaw przedsiębiorczości pomagają im w przygotowaniu się do dalszego życia społecznego i gospodarczego oraz którym zagadnieniom na lekcjach poświęcono, według uczniów, za dużo czasu, a którym - za mało.
\end{abstract}

\begin{abstract}
The Basics of Entrepreneurship is a subject, which helps the young people to understand the mechanisms according to which market economy functions, prepares them to plan their future professional careers, shapes their competences in efficient communication and prepares them to design and realize their undertakings in the surrounding environment.

This article is to present the views of the youth upon several issues connected with realizing the curriculum of 'The Basics of Entrepreneurship' in secondary schools. The article will include results of research conducted in March 2013 on the 1st and 3rd grade upper secondary school students of a comprehensive school in Andrychow. The research was carried out to analyze the aims, tasks and content of education of the Basics of Entrepreneurship subject. The main goal of the research was to determine the opinion of students on the usefulness of particular topics in the adult life and which areas of the subject seem the most interesting to them. The analysis of the responses allowed to show how diversified the expectations and interests of the 1st grade students are, and how different these are from the ones of the 3 rd grade student. The students were asked, among others, if the content presented during classes helped them to prepare themselves for their adult lives in the social-economic environment, as well as which topics in their opinion received too much or too little attention.
\end{abstract}


Słowa kluczowe: gospodarka rynkowa; przedsiębiorczość; reforma szkolna; szkoła; życie społeczno-gospodarcze

Key words: market economy; school reform; school; social-economic environment

\section{Wprowadzenie}

W 2002 r. do polskich szkół ponadgimnazjalnych został wprowadzony przedmiot podstawy przedsiębiorczości. Zgodnie z Rozporządzeniem Ministra Edukacji Narodowej i Sportu z dnia 26 lutego 2002 r. w sprawie podstawy programowej wychowania przedszkolnego, ksztatcenia ogólnego w poszczególnych typach szkół na lekcjach z tego przedmiotu uczniowie mają uczyć się postaw przedsiębiorczych oraz przygotowywać się do aktywnego udziału w życiu społeczno-gospodarczym. Przedmiot podstawy przedsiębiorczości pomaga zrozumieć młodemu człowiekowi mechanizmy funkcjonowania gospodarki rynkowej, przygotowuje do planowania przyszłej kariery zawodowej, kształtuje kompetencje sprawnego komunikowania się, a także przygotowuje do planowania i realizacji przedsięwzięć w otaczającym go środowisku.

Niniejszy artykuł ma na celu ukazanie poglądów młodzieży dotyczących kilku spraw związanych $\mathrm{z}$ realizacją przedmiotu podstawy przedsiębiorczości w szkołach ponadgimnazjalnych. Od 2012 r. obowiązkowo wprowadzono przedmiot podstawy przedsiębiorczości w klasach pierwszych liceum ogólnokształcącego.

\section{Cel i metody badań}

Badania podjęto, aby dokonać analizy realizacji celów, zadań oraz treści kształcenia przedmiotu podstawy przedsiębiorczości. Głównym celem badań było zapoznanie się z opinią uczniów, które zagadania - według nich - są najbardziej przydatne w życiu dorosłym oraz które zagadnienia i treści najbardziej ich interesują. Analiza ankiet ukazała, jak bardzo różnią się zainteresowania i oczekiwania uczniów klas pierwszych i trzecich.

Uczniowie odpowiadali m.in. na pytania, czy treści przekazywane na lekcjach podstaw przedsiębiorczości pomagają im w przygotowaniu się do dalszego życia społeczno-gospodarczego oraz którym zagadnieniom na lekcjach poświęcono, według uczniów, za dużo czasu, a którym - za mało. W artykule zostały przedstawione wyniki badań, które zostały przeprowadzone w drugim tygodnia kwietnia 2013 r. na uczniach klas trzecich oraz pierwszych w Liceum Ogólnokształcącym im. Marii Skłodowskiej-Curie w Andrychowie.

W sumie w badaniu wzięło udział 395 uczniów (197 uczniów klas pierwszych i 198 uczniów klas trzecich), którzy uczęszczają do siedmiu oddziałów klas pierwszych i ośmiu oddziałów klas trzecich. Podczas badania w klasach pierwszych nieobecnych było 21 osób, a w klasach trzecich -27 osób. Po analizie ankiet odrzucono cztery z nich z powodu nieczytelności oraz nierzetelności w odpowiedziach (uczniowie klas pierwszych).

Ostatecznie uzyskano 391 ankiet, w tym 193 z klas pierwszych i 198 z klas trzecich. Ankieta składała się z 10 pytań (8 pytań ze skalą Likerta).

Podręcznik, którym posługują się uczniowie w andrychowskim liceum, to książka autorstwa Tomasza Rachwała oraz Zbigniewa Makieły Krok w przedsiębiorczość, wydana w Warszawie w 2012 r. przez wydawnictwo Nowa Era (Makieła, Rachwał, 2012).

\section{Wyniki badań}

Na początku badań istotne wydało się zapytanie uczniów, czy wprowadzenie nowego przedmiotu podstawy przedsiębiorczości do szkół ponadgimnazjalnych i jego funkcjonowanie uważają za słuszny krok w polskiej edukacji. Wyniki badań prezentuje ryc. 1. 
Ryc. 1. Opinie uczniów na temat słuszności wprowadzenia przedmiotu podstawy przedsiębiorczości w szkołach ponadgimnazjalnych

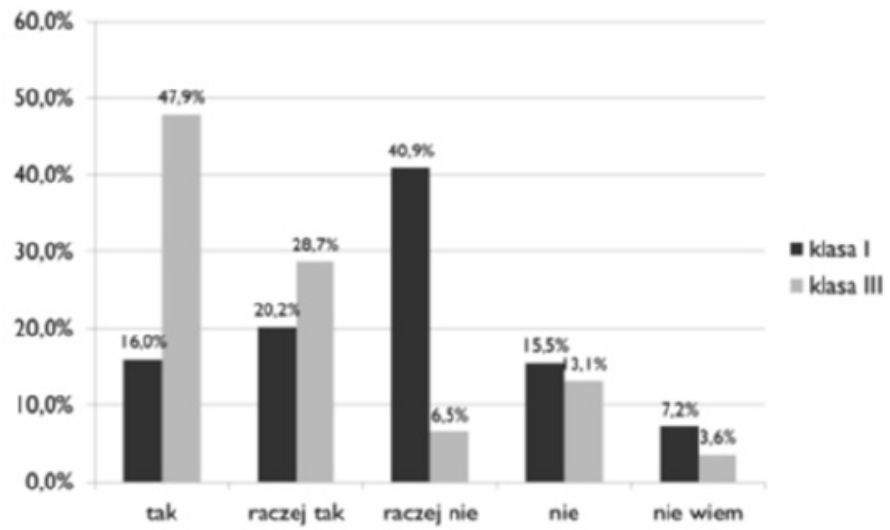

Źródło: opracowanie własne autorki na podstawie badań ankietowych w Liceum Ogólnokształcącym w Andrychowie przeprowadzonych wśród uczniów klas pierwszych i trzecich.

Prawie 48\% uczniów klas trzecich uważa, że wprowadzenie przedmiotu podstawy przedsiębiorczości do szkół ponadgimnazjalnych jest słuszne, tylko 6,5\% z nich nie podziela tego zdania. Inną opinie wyraziły klasy pierwsze, które twierdzą, że wprowadzenie przedmiotu podstawy przedsiębiorczości do szkół ponadgimnazjalnych nie jest dobrym pomysłem. Tak twierdzi 109 uczniów spośród 193 pierwszoklasistów.

Uczniowie klas pierwszych i trzecich andrychowskiego liceum zostali zapytani o ocenę podręcznika, z którego korzystają. Ankietowanych zapytano, czy treści przekazywane w podręczniku są dla nich czytelne i zrozumiałe.

59\% uczniów klas trzecich odpowiedziało, że tak, natomiast z klas pierwszych takiej samej odpowiedzi udzieliło 43\% respondentów, co stanowiło 83 osoby spośród 193 badanych (ryc. 2).

Ryc. 2. Odpowiedzi na pytanie: Czy treści przedstawione w podręczniku są dla Ciebie czytelne i zrozumiałe?

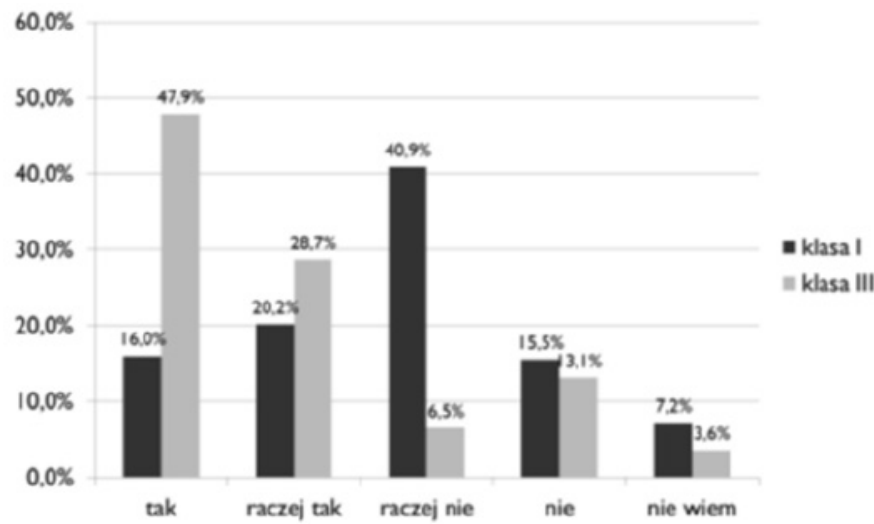

Źródło: opracowanie własne autorki na podstawie badań ankietowych w Liceum Ogólnokształcącym w Andrychowie przeprowadzonych wśród uczniów klas pierwszych i trzecich. 
Interesujące wydają się wypowiedzi młodzieży licealnej dotyczące wykorzystania treści przekazywanych na lekcjach podstaw przedsiębiorczości w dalszym, dorosłym życiu społeczno-gospodarczym. W przeprowadzonych badaniach ponad $46 \%$ ankietowanych z klas trzecich uważało, że w przyszłości wykorzysta wiadomości i umiejętności zdobyte na lekcjach podstaw przedsiębiorczości. Klasy pierwsze nie zgadzają się z tą opinią i tylko 20,7\% z nich deklaruje, że w przyszłości wykorzysta umiejętności zdobyte na lekcji podstaw przedsiębiorczości (ryc. 3).

Ryc. 3. Opinie uczniów na temat wykorzystania treści przekazywanych na lekcjach podstaw przedsiębiorczości w przygotowaniu ich do dalszego życia społeczno-gospodarczego

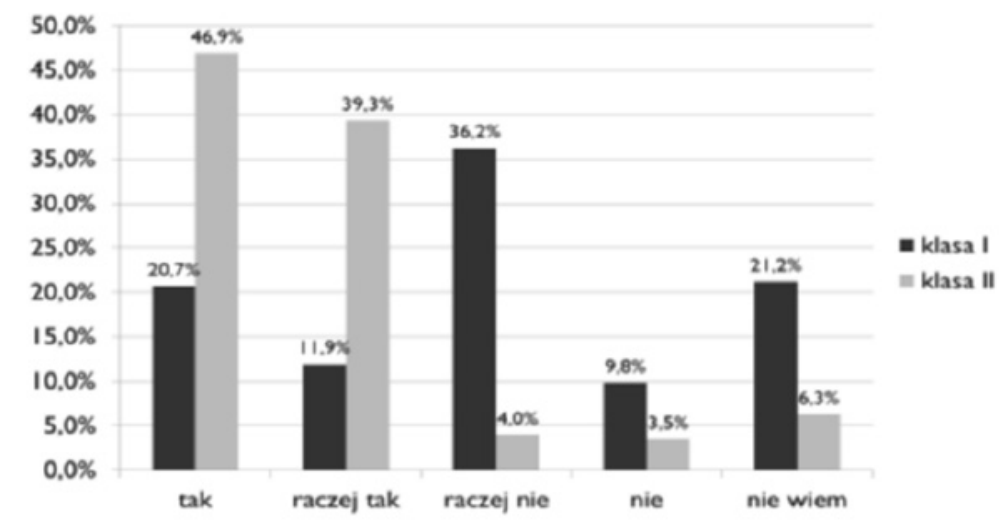

Źródło: opracowanie własne autorki na podstawie badań ankietowych w Liceum Ogólnokształcącym w Andrychowie przeprowadzonych wśród uczniów klas pierwszych i trzecich.

Zapytano też uczniów o najbardziej interesujące ich treści kształcenia, które wyodrębnione zostały (przez autorkę badań i artykułu) według działów tematycznych przyjętych z programu nauczania podstaw przedsiębiorczości autorstwa Z. Makieły i T. Rachwała (2012, wydawnictwo Nowa Era). Wyniki uzyskane w badaniach ankietowych przeprowadzonych w 2012 r. prezentuje rycina 4.

Ryc. 4. Najbardziej interesujące treści kształcenia w opinii uczniów.

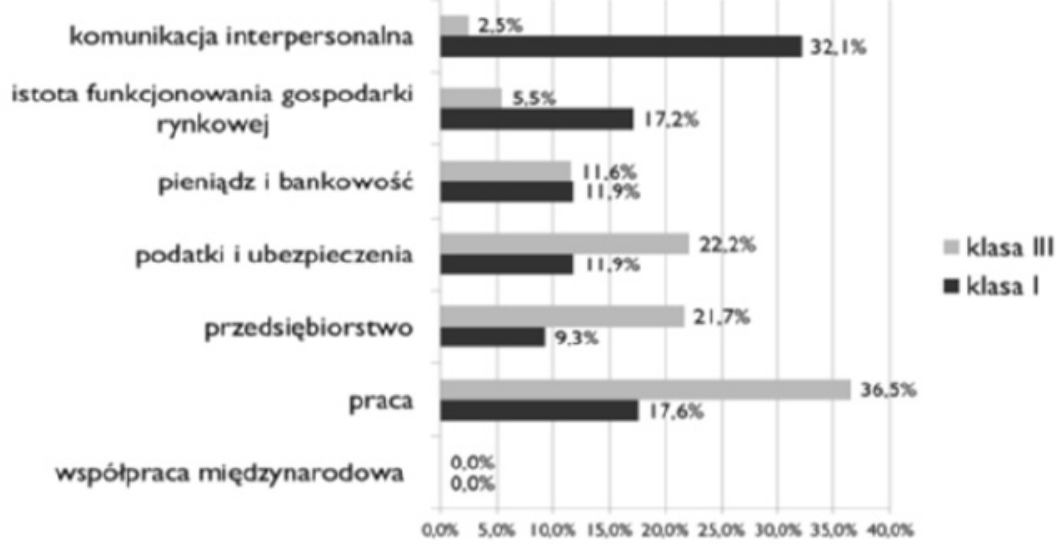

Źródło: opracowanie własne autorki na podstawie badań ankietowych w Liceum Ogólnokształcącym w Andrychowie przeprowadzonych wśród uczniów klas pierwszych i trzecich. 
Najwięcej ankietowanych uczniów z klas trzecich interesuje się zagadnieniami dotyczącymi problematyki pracy $(36,5 \%)$, podatków i ubezpieczeń $(22,2 \%)$ oraz przedsiębiorstwem $(21,7 \%)$. Związane jest to zapewne $\mathrm{z}$ wchodzeniem w dorosłe życie i zainteresowaniami związanymi z podjęciem pracy, która czeka ich w niedalekiej przyszłości. Zainteresowanie uczniów klas trzecich tematami związanymi z przedsiębiorstwem wiąże się z chęcią poznania przez nich etapów zakładania przedsiębiorstw i funkcjonowania na współczesnym, globalnym rynku. Klasy pierwsze interesują zupełnie inne zagadnienia. Najwięcej ankietowanych uczniów z klas pierwszych interesuje zagadnienie związane z komunikacją interpersonalną (32,1\%). Dopiero na drugim miejscu znalazły się zagadnienia związane z pracą (17,6\%) oraz z funkcjonowaniem gospodarki rynkowej (17,2\%). Nikt z klas pierwszych oraz trzecich nie zaznaczył odpowiedzi związanych ze współpracą międzynarodową. W chwili przeprowadzania ankiet żadna z klas w andrychowskim liceum ogólnokształcącym na przedmiocie podstawy przedsiębiorczości nie realizowała tych zagadnień na lekcjach.

Istotnym zagadnieniem w badaniu wydaje się chęć poznania opinii uczniów, którym - według nich - zagadnieniom na przedmiocie podstawy przedsiębiorczości poświęcono za dużo czasu, a którym - za mało. Odpowiedzi uczniów na to pytanie obrazuje tabela 1.

Klasy trzecie jednoznacznie wskazały, że według ich opinii za dużo czasu poświęcono na lekcjach zagadnieniom związanym z mocnymi i słabymi cechami własnej osobowości, umiejętnościami podejmowania decyzji (45\%), budżetem gospodarstwa domowego $(42,9 \%)$ oraz tematom związanymi z rolą państwa w gospodarce $(50,5 \%)$. Natomiast według klas trzecich za mało poświęcona czasu zagadnieniom związanym z poszukiwaniem pracy przez młode osoby $(62,1 \%)$, bezrobociem i próbą zwalczania go w naszym kraju (54\%) oraz emeryturą i ubezpieczeniom społecznym (51\%).

Uczniowie klas pierwszych, jak pokazały ankiety, nie są jeszcze zainteresowani zagadnieniami związanymi z rynkiem pracy oraz funkcjonowaniem przedsiębiorstw. Według klas pierwszych tym tematom poświęcono za dużo czasu na lekcjach $(40,4 \%)$, podobnie jak treściom związanym z rolą państwa w gospodarce $(52,8 \%)$. Klasy pierwsze natomiast, w przeciwieństwie do klas trzecich, chętnie poświęciłyby na lekcjach więcej czasu zagadnieniom związanym z mocnymi i słabymi cechami własnej osobowości $(39,4 \%)$.

Kolejnym ważnym pytaniem w ankiecie było zapytanie uczniów, w jakim stopniu treści omawiane na lekcji są, według nich, przydatne w codziennym życiu (tab. 2).

Podobnie jak w poprzednim pytaniu, uczniowie klas trzecich wskazali większość zagadnień omawianych na lekcjach podstaw przedsiębiorczości jako przydatne w życiu dorosłym. Najbardziej przydatnymi kwestiami, według nich, są zagadnienia związane z rynkiem pracy i bezrobociem (64,6\%), poszukiwaniem pracy i prawami pracowniczymi (45,9\%), emeryturami i ubezpieczeniem społecznym $(44,4 \%)$ oraz planowaniem podjęcia działalności gospodarczej (44,9\%). Uczniowie klas pierwszych na to pytanie odpowiedzieli inaczej. Uważają bowiem, że najbardziej przydatne w życiu są kwestie związane z mocnymi i słabymi cechami osobowości $(35,8 \%)$. Według klas pierwszych nieprzydatne są natomiast kwestie związane z funkcjonowaniem przedsiębiorstwa (29\%).

Dużą rolę w procesie dydaktycznym musi odgrywać praktyka i umiejętność posługiwania się dokumentami potrzebnymi w życiu społeczno-gospodarczym. Dlatego uzasadnione jest pytanie, w którym uczniowie odpowiadali, jakie praktyczne umiejętności posiedli na lekcjach podstaw przedsiębiorczości. Szczegółowe dane przedstawia tabela 3.

Klasy trzecie zadeklarowały, że podczas zajęć nauczyły się: pisać CV (77,2\%), wypełniać zeznanie PIT (75,2\%), wykonywać biznes plan (73,2\%), planować swój rozwój zawodowy (66,7\%). Klasy trzecie nie umieją przewidzieć opłacalności przedsięwzięcia gospodarczego (69,7\%). 
Tab. 1. Odpowiedzi na pytanie: Którym zagadnieniom na przedmiocie podstawy przedsiębiorczości poświęcono, według Twojej oceny, za dużo czasu, a którym - za mało?

\begin{tabular}{|c|c|c|c|c|c|c|c|c|c|c|}
\hline \multirow[t]{2}{*}{ Wyszczególnienie } & \multicolumn{2}{|c|}{$\begin{array}{l}\text { Bylo tego za } \\
\text { mało (w \%) }\end{array}$} & \multicolumn{2}{|c|}{$\begin{array}{c}\text { Było w sam } \\
\operatorname{raz}(\mathbf{w} \%)\end{array}$} & \multicolumn{2}{|c|}{$\begin{array}{l}\text { Było za dużo } \\
\text { (w \%) }\end{array}$} & \multicolumn{2}{|c|}{$\begin{array}{c}\text { Trudno } \\
\text { powiedzieć } \\
(\mathbf{w} \%)\end{array}$} & \multicolumn{2}{|c|}{$\begin{array}{c}\text { Nie bylo o tym } \\
\text { mowy na } \\
\text { lekcji (w \%) }\end{array}$} \\
\hline & kl. I & kl. III & kl. I & kl. III & kl. I & kl. III & kl. I & kl. III & kl. I & kl. III \\
\hline $\begin{array}{l}\text { Mocne i słabe } \\
\text { cechy własnej } \\
\text { osobowości, } \\
\text { asertywność, } \\
\text { umiejętność } \\
\text { podejmowania } \\
\text { decyzji itp. }\end{array}$ & 39,4 & 5,1 & 30,6 & 15,2 & 13,5 & 45,0 & 16,6 & 34,8 & 0 & 0 \\
\hline $\begin{array}{l}\text { Funkcjonowanie } \\
\text { rynku i gospodarki } \\
\text { rynkowej }\end{array}$ & 3,6 & 7,6 & 58,0 & 62,1 & 17,6 & 20,2 & 20,7 & 15,1 & 0 & 0 \\
\hline $\begin{array}{l}\text { Budżet gospodar- } \\
\text { stwa domowego }\end{array}$ & 15,5 & 10,1 & 57,0 & 15,1 & 8,8 & 42,9 & 18,6 & 31,8 & 0 & 0 \\
\hline $\begin{array}{l}\text { Emerytura } \\
\text { i ubezpieczenia } \\
\text { społeczne }\end{array}$ & 6,2 & 51 & 50,2 & 24,8 & 31,6 & 10,1 & 11,9 & 14,1 & 0 & 0 \\
\hline $\begin{array}{l}\text { Przedsiębiorstwo } \\
\text { w gospodarce. } \\
\text { Funkcjonowanie } \\
\text { przedsiębiorstwa }\end{array}$ & 17,1 & 5,1 & 35,7 & 34,8 & 40,4 & 15,1 & 6,7 & 44,9 & 0 & 0 \\
\hline $\begin{array}{l}\text { Planowanie } \\
\text { podjęcia działalno- } \\
\text { ści gospodarczej }\end{array}$ & 14,5 & 45,0 & 37,8 & 21,2 & 38,3 & 6,6 & 9,3 & 28,8 & 0 & 0 \\
\hline $\begin{array}{l}\text { Poszukiwanie } \\
\text { pracy, nawiązywa- } \\
\text { nie stosunku pracy, } \\
\text { prawa pracownika }\end{array}$ & 24,8 & 62,1 & 35,2 & 20,2 & 23,8 & 2,5 & 16,1 & 15,1 & 0 & 0 \\
\hline $\begin{array}{l}\text { Rola państwa } \\
\text { w gospodarce }\end{array}$ & 22,8 & 13,6 & 14,5 & 11,6 & 52,8 & 50,5 & 9,8 & 19,7 & 0 & 0 \\
\hline Pieniądz i banki & 9,8 & 38,8 & 47,6 & 15,1 & 30,5 & 19,2 & 11,9 & 26,8 & 0 & 0 \\
\hline $\begin{array}{l}\text { Rynek pracy } \\
\text { i bezrobocie }\end{array}$ & 21,2 & 54,0 & 45,0 & 30,8 & 17,6 & 5,5 & 16,1 & 9,6 & 0 & 0 \\
\hline $\begin{array}{l}\text { Współpraca } \\
\text { gospodarcza Polski } \\
\text { z zagranicą }\end{array}$ & 0,0 & 0,0 & 0,0 & 0,0 & 0,0 & 0,0 & 0,0 & 0,0 & 100 & 100 \\
\hline Etyka biznesu & 0,0 & 0,0 & 0,0 & 0,0 & 0,0 & 0,0 & 0,0 & 0,0 & 100 & 100 \\
\hline
\end{tabular}

Źródło: opracowanie własne autorki na podstawie badań ankietowych w Liceum Ogólnokształcącym w Andrychowie przeprowadzonych wśród uczniów klas pierwszych i trzecich. 
Tab. 2. Odpowiedzi na pytanie: W jakim stopniu wymienione kwestie wydają Ci się przydatne w życiu?

\begin{tabular}{|c|c|c|c|c|c|c|c|c|c|c|}
\hline \multirow[t]{2}{*}{ Wyszczególnienie } & \multicolumn{2}{|c|}{$\begin{array}{c}\text { W ogóle } \\
\text { nieprzydatne } \\
(w \%)\end{array}$} & \multicolumn{2}{|c|}{$\begin{array}{c}\text { Raczej } \\
\text { nieprzydatne } \\
(w \%)\end{array}$} & \multicolumn{2}{|c|}{$\begin{array}{l}\text { Ani przydat- } \\
\text { ne, ani } \\
\text { nieprzydatne } \\
(w \%)\end{array}$} & \multicolumn{2}{|c|}{$\begin{array}{l}\text { Raczej } \\
\text { przydatne } \\
(\mathbf{w} \%)\end{array}$} & \multicolumn{2}{|c|}{$\begin{array}{l}\text { Bardzo } \\
\text { przydatne } \\
\text { (w \%) }\end{array}$} \\
\hline & kl. I & kl. III & kl. I & kl. III & kl. I & kl. III & kl. I & kl. III & kl. I & kl. III \\
\hline $\begin{array}{l}\text { Mocne i słabe } \\
\text { cechy własnej } \\
\text { osobowości, } \\
\text { asertywność, } \\
\text { umiejętność } \\
\text { podejmowania } \\
\text { decyzji, itp. }\end{array}$ & 0,5 & 10,6 & 5,2 & 17,2 & 18,1 & 33,9 & 40,3 & 19,7 & 35,8 & 19,2 \\
\hline $\begin{array}{l}\text { Funkcjonowanie } \\
\text { rynku i gospodarki } \\
\text { rynkowej }\end{array}$ & 19,7 & 8,6 & 7,7 & 23,7 & 46,1 & 32,3 & 6,2 & 19,2 & 20,2 & 16,2 \\
\hline $\begin{array}{l}\text { Budżet gospodar- } \\
\text { stwa domowego }\end{array}$ & 6,7 & 13,6 & 14,5 & 16,6 & 26,9 & 24,2 & 17 & 28,8 & 34,7 & 16,6 \\
\hline $\begin{array}{l}\text { Emerytura } \\
\text { i ubezpieczenia } \\
\text { społeczne }\end{array}$ & 5,7 & 0,0 & 6,7 & 5,5 & 32,6 & 17,2 & 32,6 & 33,3 & 22,3 & 44,4 \\
\hline $\begin{array}{l}\text { Przedsiębiorstwo } \\
\text { w gospodarce. } \\
\text { Funkcjonowanie } \\
\text { przedsiębiorstwa }\end{array}$ & 29 & 5,5 & 19,2 & 5,5 & 10,8 & 11,6 & 23,8 & 41,4 & 17,1 & 36,9 \\
\hline $\begin{array}{l}\text { Planowanie } \\
\text { podjęcia } \\
\text { działalności } \\
\text { gospodarczej }\end{array}$ & 10,4 & 5,5 & 18,6 & 5,5 & 21,2 & 9,1 & 26,4 & 35,8 & 18,1 & 44,9 \\
\hline $\begin{array}{l}\text { Poszukiwanie } \\
\text { pracy, nawią-zywa- } \\
\text { nie stosunku pracy, } \\
\text { prawa pracownika }\end{array}$ & 5,2 & 0,0 & 4,1 & 11,6 & 18,1 & 12,1 & 47,1 & 20,7 & 25,4 & 45,9 \\
\hline $\begin{array}{l}\text { Rola państwa } \\
\text { w gospodarce }\end{array}$ & 5,2 & 0,0 & 10,4 & 0,0 & 6,7 & 3,5 & 34,7 & 46,9 & 43 & 49,5 \\
\hline Pieniądz i banki & 10,4 & 6,1 & 20,7 & 6,1 & 46,1 & 26,3 & 5,7 & 49,5 & 11,9 & 12,1 \\
\hline $\begin{array}{l}\text { Rynek pracy } \\
\text { i bezrobocie }\end{array}$ & 16,6 & 0,0 & 20,7 & 0,0 & 25,9 & 10,1 & 25,9 & 25,2 & 10,3 & 64,6 \\
\hline $\begin{array}{l}\text { Współpraca } \\
\text { gospodarcza Polski } \\
\text { z zagranicą }\end{array}$ & 18,1 & 23,7 & 17,1 & 18,7 & 45,6 & 26,3 & 8,8 & 20,2 & 10,4 & 11,1 \\
\hline Etyka biznesu & 14,5 & 10,1 & 15,5 & 11,6 & 31,1 & 11,6 & 26,9 & 31,3 & 11,9 & 35,3 \\
\hline
\end{tabular}

Źródło: opracowanie własne autorki na podstawie badań ankietowych w Liceum Ogólnokształcącym w Andrychowie przeprowadzonych wśród uczniów klas pierwszych i trzecich. 
Tab. 3. Odpowiedzi na pytanie: Czy wymienionych poniżej umiejętności nauczyłeś(aś) się na przedmiocie podstawy przedsiębiorczości?

\begin{tabular}{|l|l|l|l|l|l|l|}
\hline \multicolumn{1}{|c|}{ Wyszczególnienie } & \multicolumn{2}{c|}{$\begin{array}{c}\text { Tak } \\
\text { (w \%) }\end{array}$} & \multicolumn{2}{c|}{$\begin{array}{c}\text { Nie } \\
\text { (w \%) }\end{array}$} & \multicolumn{2}{c|}{$\begin{array}{c}\text { Trudno } \\
\text { powiedzieć } \\
\text { (w \%) }\end{array}$} \\
\cline { 2 - 8 } & kl. I & kl. III & kl. I & kl. III & kl. I & kl. III \\
\hline Jak obliczyć odsetki od lokaty. & 21,7 & 49,5 & 48,1 & 21,2 & 30,1 & 29,3 \\
\hline Jak założyć firmę. & 46,1 & 62,1 & 23,3 & 16,2 & 30,6 & 21,7 \\
\hline Jak napisać dobre CV. & 62,2 & 77,2 & 17,1 & 5,1 & 15,5 & 17,7 \\
\hline Jak wypełnić formularz PIT. & 52,3 & 75,2 & 21,8 & 13,1 & 25,9 & 12,1 \\
\hline Jak negocjować. & 31,0 & 35,3 & 23,8 & 16,2 & 45,0 & 48,5 \\
\hline Jak planować budżet gospodarstwa domowego. & 45,6 & 35,3 & 19,2 & 20,2 & 35,2 & 44,4 \\
\hline Jak dokonać autoprezentacji. & 14,5 & 35,8 & 65,7 & 16,2 & 21,8 & 51,3 \\
\hline Jak zaplanować swój rozwój zawodowy. & 20,7 & 66,7 & 48,1 & 13,1 & 31,0 & 20,2 \\
\hline $\begin{array}{l}\text { Jak przewidzieć opłacalność jakiegoś } \\
\text { przedsięwzięcia gospodarczego. }\end{array}$ & 16,0 & 16,2 & 74,0 & 69,7 & 9,8 & 14,1 \\
\hline Jak wykonać biznes plan. & 68,4 & 73,2 & 11,3 & 9,1 & 20,2 & 17,7 \\
\hline
\end{tabular}

Źródło: opracowanie własne autorki na podstawie badań ankietowych w Liceum Ogólnokształcącym w Andrychowie przeprowadzonych wśród uczniów klas pierwszych i trzecich.

Klasy pierwsze na lekcjach podstaw przedsiębiorczości nauczyły się: wykonywać biznes plan $(68,4 \%)$ oraz pisać CV (62,2\%). Uczniowie klas pierwszych nie potrafią, podobnie jak klas trzecich, przewidzieć opłacalności przedsięwzięcia gospodarczego (74\%) oraz dokonać autoprezentacji $(65,7 \%)$.

Ostatnie pytanie miało na celu poznanie opinii uczniów, co sądzą na temat przeprowadzonej reformy i czy przedmiot podstawy przedsiębiorczości - według nich - jest przedmiotem ważnym i należy go nauczać we wszystkich typach szkół ponadgimnazjalnych. Odpowiedzi na poszczególne pytanie pokazuje tabela 4 .

Uczniowie klas trzecich uważają, że przedmiot podstawy przedsiębiorczości nie powinien być nauczany w klasie pierwszej (51,5\%), lecz w klasie trzeciej (34,8\%). Innego zdania są uczniowie klas pierwszych, którzy uważają, że przedmiot ten powinien być realizowany w programie klasy pierwszej (39,3\%).

Uczniowie klas trzecich zdecydowanie nie zgadzają się z opinią, że przedmiot podstawy przedsiębiorczości jest przedmiotem mało ważnym w szkole $(21,7 \%)$ i powinien zniknąć z programu szkolnego (26,7\%). Klasy pierwsze twierdzą, że przedmiot podstawy przedsiębiorczości powinien być nauczany tylko w szkołach ekonomicznych $(32,6 \%)$ i powinien zniknąć z programu szkolnego $(19,6 \%)$. 
Tab. 4. Odpowiedzi na pytanie: W jakim stopniu zgadzasz się z każdym z niżej przedstawionych twierdzeń?

\begin{tabular}{|c|c|c|c|c|c|c|c|c|c|c|}
\hline \multirow[t]{2}{*}{ Wyszczególnienie } & \multicolumn{2}{|c|}{$\begin{array}{l}\text { Zdecydo- } \\
\text { wanie się } \\
\text { nie } \\
\text { zgadzam } \\
\text { (w \%) }\end{array}$} & \multicolumn{2}{|c|}{$\begin{array}{l}\text { Raczej się } \\
\text { nie } \\
\text { zgadzam } \\
(\mathbf{w} \%)\end{array}$} & \multicolumn{2}{|c|}{$\begin{array}{l}\text { Trudno } \\
\text { powiedzieć } \\
(\mathbf{w} \%)\end{array}$} & \multicolumn{2}{|c|}{$\begin{array}{c}\text { Raczej się } \\
\text { zgadzam } \\
(\mathbf{w} \%)\end{array}$} & \multicolumn{2}{|c|}{$\begin{array}{l}\text { Zdecydo- } \\
\text { wanie się } \\
\text { zgadzam } \\
(\mathbf{w} \%)\end{array}$} \\
\hline & $\begin{array}{c}\text { kl. } \\
\text { I }\end{array}$ & $\begin{array}{l}\text { kl. } \\
\text { III }\end{array}$ & $\begin{array}{c}\text { kl. } \\
\text { I }\end{array}$ & $\begin{array}{l}\text { kl. } \\
\text { III }\end{array}$ & $\begin{array}{c}\text { kl. } \\
\text { I }\end{array}$ & $\begin{array}{l}\text { kl. } \\
\text { III }\end{array}$ & $\begin{array}{c}\text { kl. } \\
\text { I }\end{array}$ & $\begin{array}{l}\text { kl. } \\
\text { III }\end{array}$ & $\begin{array}{c}\text { kl. } \\
\text { I }\end{array}$ & $\begin{array}{l}\text { kl. } \\
\text { III }\end{array}$ \\
\hline $\begin{array}{l}\text { Podstawy przedsiębiorczości } \\
\text { to przedmiot mało ważny } \\
\text { w szkole }\end{array}$ & 3,1 & 21,7 & 3,1 & 26,7 & 20,7 & 32,3 & 45 & 10,1 & 27,9 & 9 \\
\hline $\begin{array}{l}\text { Włożyłem(am) dużo pracy } \\
\text { w opanowanie treści przedmiotu } \\
\text { podstawy przedsiębiorczości }\end{array}$ & 10,3 & 21,2 & 24,8 & 6,0 & 38,8 & 42,9 & 5,2 & 23,7 & 20,7 & 6,1 \\
\hline $\begin{array}{l}\text { Podstawy przedsiębiorczości } \\
\text { powinny zniknąć z programu } \\
\text { szkolnego }\end{array}$ & 6,2 & 26,7 & 4,1 & 31,3 & 46,1 & 33,8 & 23,8 & 4,5 & 19,6 & 3,5 \\
\hline $\begin{array}{l}\text { Przedmiot podstawy } \\
\text { przedsiębiorczości powinien } \\
\text { być nauczany tylko w szkołach } \\
\text { ekonomicznych }\end{array}$ & 5,2 & 23,7 & 6,2 & 28,2 & 22,2 & 31,8 & 33,6 & 5,1 & 32,6 & 11,1 \\
\hline $\begin{array}{l}\text { Przedmiot podstawy } \\
\text { przedsiębiorczości powinien być } \\
\text { nauczany w III klasie liceum }\end{array}$ & 24,8 & 10,1 & 16,6 & 6,5 & 49,2 & 26,7 & 6,2 & 21,7 & 3,1 & 34,8 \\
\hline $\begin{array}{l}\text { Przedmiot podstawy } \\
\text { przedsiębiorczości powinien } \\
\text { być nauczany w I klasie liceum }\end{array}$ & 10,3 & 51,5 & 0,5 & 26,2 & 42,4 & 9,6 & 39,3 & 6,6 & 29,0 & 6,0 \\
\hline
\end{tabular}

Źródło: opracowanie własne autorki na podstawie badań ankietowych w Liceum Ogólnokształcącym w Andrychowie przeprowadzonych wśród uczniów klas pierwszych i trzecich.

\section{Podsumowanie}

Z przeprowadzonych badań wynika, że przedmiot podstawy przedsiębiorczości spełnia oczekiwania większości ankietowanych uczniów. Wydaje się także, że wśród uczniów andrychowskiego liceum podstawy przedsiębiorczości w obecnej formie są przedmiotem praktycznym, ale mało konkretnym, bez solidnej podbudowy teoretycznej. Młodzi ludzie mają wyraźnie sprecyzowaną ścieżkę swojej kariery zawodowej i na tym etapie nie oczekują innych propozycji czy zmian. Pochłonięci pasją nauki w swoich specjalnościach i profilach, nie interesują się praktycznymi rozwiązaniami, na które być może przyjdzie czas w późniejszych latach. Na podstawie przeprowadzonych ankiet można wyciągnąć następujące wnioski:

- uczniowie klas trzecich zdecydowanie uważają, że wprowadzenie do szkół ponadgimnazjalnych przedmiotu podstawy przedsiębiorczości jest potrzebne (47,9\%), natomiast tylko $16 \%$ uczniów klas pierwszych podziela tę opinię;

- treści kształcenia, które najbardziej interesują uczniów klas pierwszych, to komunikacja interpersonalna $(32,1 \%)$, klasy trzecie najbardziej interesuje rozdział poświęcony pracy $(36,5 \%)$; 
- według klas trzecich i pierwszych na przedmiocie podstawy przedsiębiorczości poświęcono za dużo czasu na zagadnienie związane z rolą państwa w gospodarce - $(50,5 \%)$ klasy trzecie, $(52,8 \%)$ klasy pierwsze;

- według klas trzecich na przedmiocie podstawy przedsiębiorczości poświęcono za mało czasu na zagadnienie związane z poszukiwaniem pracy, prawami pracowników $(62,1 \%)$, według klas pierwszych były to zagadnienia związane z mocnymi i słabymi stronami własnej osobowości, umiejętnościami podejmowania decyzji (39,4\%);

- według klas trzecich najbardziej przydatne w życiu wydają się zagadnienia związane z rynkiem pracy i bezrobociem $(64,6 \%)$, poszukiwaniem pracy i prawami pracowniczymi (49,5\%), planowaniem podjęcia działalności gospodarczej $(44,9 \%)$ oraz emeryturami i ubezpieczeniami społecznymi (44,4\%);

- według klas pierwszych najbardziej przydatne w życiu wydają się zagadnienia związane z rolą państwa w gospodarce $(43 \%)$ oraz budżetem gospodarstwa domowego $(34,7 \%)$;

- według klas trzecich najmniej przydatne w życiu wydają się zagadnienia związane ze współpracą gospodarczą Polski z zagranicą (23,7\%); według klas pierwszych: funkcjonowanie rynku i gospodarki rynkowej (19,7\%);

- uczniowie klas trzecich deklarują, że na przedmiocie podstawy przedsiębiorczości nauczyli się: pisać CV - (77,2\%), wypełniać formularz PIT - (75,2\%), wykonywać biznes plan (73,2\%); deklarują natomiast, że nie nauczyli się, jak przewidzieć opłacalność jakiegoś przedsiębiorstwa $(69,7 \%)$;

- uczniowie klas pierwszych deklarują, że na przedmiocie podstawy przedsiębiorczości nauczyli się: wykonywać biznes plan $(68,4 \%)$, pisać CV (62, 2\%), natomiast deklarują, że nie nauczyli się dokonywać autoprezentacji (65,7\%);

- uczniowie klas trzecich uważają, że przedmiot podstawy przedsiębiorczości powinien być nauczany w klasie trzeciej (34,8\%); (51,5\%) zdecydowanie deklaruje, że przedmiot ten nie powinien być nauczany w klasie pierwszej, 29\% uczniów klas pierwszych podziela tę opinię;

- klasy pierwsze uważają, że przedmiot podstawy przedsiębiorczości to przedmiot mało ważny w szkole (45\%) i powinien być nauczany tylko w szkołach ekonomicznych $(33,6 \%)$, tak też uważa $(32,6 \%)$ uczniów klas trzecich.

Bardzo ważną rolę w procesie dydaktycznym odgrywa nauczyciel. To on powinien pobudzać uczniów do twórczego zachowania oraz inspirować ich do działań. W andrychowskim liceum ogólnokształcącym w roku szkolnym 2012/2013 przedmiotu podstawy przedsiębiorczości w 15 oddziałach uczyło w sumie trzech nauczycieli. Ważne jest, aby nauczyciel przedsiębiorczości miał autorytet wśród swoich uczniów i ich aktywizował. Na pewno wysoko ceniony jest nauczyciel kreatywny i mający wiedzę merytoryczną z przedmiotu. To w dużej mierze od nauczyciela zależy, czy uczniowie polubią dany przedmiot i czy zdobyta na lekcjach wiedza będzie wykorzystywana w późniejszym dorosłym życiu. O kompetencjach przedmiotowych i dydaktycznych nauczycieli geografii, w tym także uczących podstaw przedsiębiorczości, pisał w obszernej monografii W. Osuch (Osuch, 2010), wskazując przykłady kształtowania wybranych kompetencji w toku studiów i pracy zawodowej nauczycieli. Ważnymi kompetencjami, nie tylko u nauczycieli przedsiębiorczości, są kompetencje komunikacyjne, co było przedmiotem rozważań W. Osucha (2011), jak również zostało potwierdzone w wynikach badań ankietowych, zwłaszcza wśród rodziców krakowskich liceów. O kompetencjach odnoszących się bezpośrednio do przedsiębiorczości i postaw przedsiębiorczych pisali: S. Dorocki, W. Kilar i T. Rachwał (2011), podkreślając także kreatywność, innowacyjność i podejmowanie ryzyka, a także planowanie przedsięwzięć dla potrzeb osiągania zamierzonych celów. Autorzy przypomnieli również kompetencje kluczowe, stosowane w europejskim obszarze 
edukacyjnym. Kompetencje biznesowe i społeczne uczniów gimnazjum są przedmiotem projektu badawczego FIFOBI w zakresie przygotowania gimnazjalistów do prowadzenia działalności gospodarczej (Kurek, Rachwał, 2010).

Czas pokaże, czy proponowane zmiany wprowadzenia do klas pierwszych szkoły ponadgimnazjalnej przedmiotu podstawy przedsiębiorczości będą korzystne. Czy nowa reforma z 2012 r. wyjdzie naprzeciw wszystkim uczniom, także uczniom wybitnie zdolnym, i czy zainteresowanie przedmiotem oraz wykorzystanie treści kształcenia przedsiębiorczości w karierze zawodowej i życiu społeczno-gospodarczym będzie większe. Postawione przed dzisiejszą szkołą zadanie wykształcenia młodych ludzi, którzy będą potrafili odnaleźć się w szybko zmieniających się procesach gospodarki rynkowej, wydaje się być bardzo ambitnym.

\section{Literatura \\ References}

Dorocki, S., Kilar, W., Rachwał, T. (2011). Założenia i cele Projektu „Krok w przedsiębiorczość” dla nauczycieli szkół ponadgimnazjalnych. Przedsiębiorczość - Edukacja, 7, 308-320.

Kurek, S., Rachwał, T. (2010). Założenia i wstępne wyniki europejskiego projektu badawczego FIFOBI w zakresie kształtowania kompetencji uczniów gimnazjum do prowadzenia działalności gospodarczej. Przedsiębiorczość - Edukacja, 6, 472-485.

Kurek, S., Rachwał, T., Szubert, M. (2012). Kształtowanie kompetencji biznesowych uczniów gimnazjum w świetle opinii nauczycieli na podstawie wyników badań prowadzonych w ramach europejskiego projektu FIFOBI. Przedsiębiorczość - Edukacja, 8, 24-36.

Makieła, Z., Rachwał, T. (2012). Krok w przedsiębiorczość. Podręcznik do podstaw przedsiębiorczości dla szkół ponadgimnazjalnych. Warszawa: wydawnictwo Nowa Era.

Osuch, E., Osuch, W. (2005). Przedmiot podstawy przedsiębiorczości w opinii uczniów i rodziców na przykładzie wybranych krakowskich szkół. Przedsiębiorczość -Edukacja, 1, 195-202.

Osuch, W. (2010). Kompetencje przedmiotowe i dydaktyczne nauczycieli geografii oraz studentów geografii - kandydatów na nauczycieli. Prace Monograficzne, 570, 304.

Osuch, W. (2011). Kompetencje w zakresie komunikacji interpersonalnej w dobie postępujących procesów globalizacji. Przedsiębiorczość - Edukacja, 7, 333-346.

Osuch, W. (2012). Podstawy przedsiębiorczości w opinii uczniów krakowskich liceów - szanse i oczekiwania. Przedsiębiorczość - Edukacja, 8, 37-47.

Rachwał, T. (2009). Ocena projektu zmian podstawy programowej podstaw przedsiębiorczości. Przedsiębiorczość - Edukacja, 5, 349-372.

Rozporzadzenie Ministra Edukacji Narodowej i Sportu z dnia 26 lutego 2002 r. w sprawie podstawy programowej wychowania przedszkolnego, ksztatcenia ogólnego w poszczególnych typach szkót (Dz.U. z 2002 Nr 51, poz. 458).

Kamila Ziólkowska-Weiss, absolwentka kulturoznawstwa na Uniwersytecie Jagiellońskim oraz geografii na Uniwersytecie Pedagogicznym im. Komisji Edukacji Narodowej w Krakowie. Ukończyła podyplomowe studia na Uniwersytecie Ekonomicznym w Krakowie na kierunku zarządzanie turystyką międzynarodową. Od 2011 r. doktorantka na Uniwersytecie Pedagogicznym na kierunku geografia. Od 2012 r. pracownik naukowy na stanowisku asystenta w Zakładzie Turystyki i Badań Regionalnych Uniwersytetu Pedagogicznego im. Komisji 
Edukacji Narodowej w Krakowie. Czynny pilot wycieczek. Autorka kilku publikacji naukowych. Główne zainteresowania naukowe autorki to turystyka kulturowa oraz mniejszości narodowe i grupy etniczne w Małopolsce.

Kamila Ziółkowska-Weiss, BA, a graduate of culture studies at the Jagiellonian University and of Geography at the Pedagogical University of Cracow.

The author has graduated from the postgraduate studies in international tourism management at the Cracow University of Economics. Since 2011, she has been a doctoral student of Geography at the Pedagogical University. Since 2012, she has been a research worker, acting as an assistant in the department of Tourism and Regional Studies at the Pedagogical University of Cracow. She is an active tourist guide. The author of several academic publications. Her main academic interests are in cultural tourism and ethnic groups in Małopolska.

Adres/Address:

Uniwersytet Pedagogiczny im. Komisji Edukacji Narodowej w Krakowie ul. Podchorążych 2 30-084 Kraków, Polska

e-mail:kamilacamela@wp.pl 